УДК 342.56:35

DOI https://doi.org/10.32849/2663-5313/2020.1.17

В'ячеслав Бойко,

канд. юрид. наук, докторант

Науково-дослідного інституту публічного права

\title{
ПОНЯТТЯ ТА ЗМІСТ АДМІНІСТРАТИВНО- ПРАВОВОГО ЗАБЕЗПЕЧЕННЯ ЕФЕКТИВНОСТІ ФУНКЦІОНУВАННЯ СУДОВОЇ ВЛАДИ УКРАЇНИ
}

У статті визначено адміністративно-правове забезпечення ефективності функиіонування судової влади України як регламентовану законодавством діяльність судової публічної адміністрації, яка здійснюється шляяхом прийняття публічних приписів, координування суб'єктів публічної адміністраиії та вчинення інших владно-розпорядчих дій, що спрямовані на реальну ефективність та створення належних умов для функиіонування судової влади з метою захисту прав, свобод та законних інтересів осіб, суспільства та держави. З'ясовано, що зміст адміністративно-правового забезпечення ефективності функиіонування судової влади - ие провідні складники адміністративно-правового забезпечення функиіонування органів судової влади, які визначають їхнє місие в суспільстві, а також створюють всі належні умови для правильного функціонування системи правосуддя та ефективності ї̈ діяльності. Доведено, що до провідних елементів змісту адміністративно-правового забезпечення ефективності функиіонування судової влади слід віднести: 1) судову публічну адміністраиію як владний суб'єкт адміністративно-правового забезпечення; 2) об'єкт адміністративно-правового забезпечення ефективності функиіонування судової влади; 3) приниипи адміністративно-правового забезпечення ефективності функиіонування судової влади; 4) адміністративно-правові відносини у сфері забезпечення ефективності функиіонування судової влади, їх зміст; 5) інші складники змісту адміністративно-правового забезпечення ефективності функиіонування судової влади. Зроблено висновок, що до особливостей адміністративно-правового забезпечення ефективності функиіонування судової влади України слід віднести таке: 1) ие певна діяльність, визначена та передбачена законодавством; 2) провідним суб'єктом є судова публічна адміністрачія; 3) спрямоване на ефективність здійснення повноважень судової гілки влади; 4) полягає у вчиненні певних публічно-організачійних дій та прийнятті владних приписів; 5) створене для функиіонування судової системи України; 6) належний стан такого забезпечення прямо пов'язаний із захистом прав, свобод та законних інтересів осіб, суспільства та держави.

Ключові слова: адміністративно-правове забезпечення, ефективність, зміст, публічна адміністрація, судова влада.

Постановка проблеми. Судова влада є самостійною та незалежною гілкою влади, яка функціонує з метою забезпечення прав, свобод та законних інтересів осіб, суспільства та держави загалом. В умовах проведення судової реформи органи судової влади перебувають у площині змін, які зумовлені євроінтеграційним напрямом. Ці зміни певною мірою спрямовані на належне забезпечення судочинства, адже стан адміністративно-правового забезпечення судової влади перебуває не на високому рівні, що негативно вливає на рівень здійснення судочинства та на ефективність функціонування правосуддя загалом.

Таким чином, для забезпечення ефективності захисту порушених прав, свобод та законних інтересів фізичних і юридичних осіб виникає необхідність у визначенні поняття та дослідженні змісту адміністративно-правового забезпечення ефективності функціонування судової влади України.
Огляд останніх досліджень. До проблематики визначення змісту адміністративноправового забезпечення ефективності функціонування судової влади зверталися такі вчені-юристи: С. Бондар, А. Борко, О. Гумін, О. Дручек, Р. Ігонін, І. Іерусалімова, О. Клименко, Я. Лазур, Н. Литвин, А. Олійник, І. Прошутя, К. Степаненко, К. Толкачев та інші. Проте аналізованих нами питань вони торкалися лише побічно, досліджуючи інші, більш загальні, спеціальні чи суміжні, виклики.

Мета статті полягає в тому, щоб на основі праць вчених-юристів визначити та окреслити поняття та зміст адміністративноправового забезпечення ефективності функціонування судової влади України.

Виклад основного матеріалу. Однією з провідних категорій у вітчизняній юриспруденції є поняття адміністративно-правового забезпечення. У нашому дослідженні йдеться 
про поняття та зміст адміністративно-правового забезпечення ефективності функціонування судової влади України. Для визначення поняття такого забезпечення необхідно визначити такі основні категорії, як «забезпечення», «правове забезпечення» та «адміністративноправове забезпечення». У тлумачному словнику «забезпечення» визначається як задоволення когось, чогось у якихось потребах, створення надійних умов для здійснення чого-небудь; гарантування чогось: забезпечення промисловості енергоносіями, забезпечення міцного миру; матеріальні засоби до існування: матеріальне забезпечення, пенсійне забезпечення, соціальне забезпечення [16, с. 400]. 3 іншого боку, забезпечення - це надання або створення матеріальних засобів; охорона кого- чого-небудь від небезпеки; гарантування чогось [15].

Таким чином, поняття «забезпечення» тлумачні словники трактують як умови гарантування чого-небудь.

Щодо визначення терміна «правове забезпечення», то теоретики права визначають його як здійснюване державою за допомогою правових норм, приписів і сукупності засобів упорядкування суспільних відносин, їх юридичне закріплення, охорону, реалізацію і розвиток [9, с. 392]. Схожу позицію займає теоретик А. Олійник, на думку якого правове забезпечення - це вплив на права і свободи громадян за допомогою певних юридичних засобів, насамперед норм права [11, с. 55]. Науковець К. Толкачов під правовим забезпеченням розуміє діяльність державних органів, громадських організацій, посадових осіб і громадян щодо здійснення своїх функцій, компетенцій, обов'язків з метою створення оптимальних умов для суворої, неухильної реалізації правових приписів та правомірного здійснення прав і свобод; результат цієї діяльності, що виражається в реалізації правових приписів, прав і свобод громадян [14, с. 100].

Отже, з огляду на позиції теоретиків права, правове забезпечення - це регламентована та передбачена законодавством діяльність держави, яка спрямована на реалізацію прав, свобод та законних інтересів іï громадян.

Проблематики визначення поняття адміністративно-правового забезпечення торкалися багато вчених. Так, науковець О. М. Гумін визначає, що адміністративно-правове забезпечення варто розглядати в широкому та вузькому розуміннях, зокрема: у широкому розумінні адміністративно-правове забезпечення - це упорядкування суспільних відносин уповноваженими на те державою органами, їх юридичне закріплення за допомогою правових норм, охорона, реалізація і розвиток. Вузьке визначення адміністративно-право- вого забезпечення буде змінюватися залежно від того, про які суспільні відносини йтиметься $[4$, с. 50].

Досліджуючи адміністративно-правове забезпечення у різних сферах суспільства, вчені по-різному визначали поняття відповідного забезпечення. Зокрема, I. О. Ієрусалімова розкриває адміністративно-правове забезпечення прав і свобод людини та громадянина як повноту регулювання за допомогою норм адміністративного права суспільних відносин, що виникають для та в процесі їх реалізації, а також надання за допомогою цих норм відповідних гарантій, які разом з іншими правовими та неправовими гарантіями утворюють стійку систему можливостей користування правовими цінностями в державі [7, с. 14]. Адміністративно-правове забезпечення у сфері господарювання О.В.Клименко окреслює як здійснюване державою за допомогою спеціальної системи упорядкування суспільних відносин, їх юридичне закріплення, реалізацію, охорону, захист і відновлення, тобто діяльність органів державної влади, спрямовану на регламентацію, створення якнайбільш сприятливої атмосфери, фактичне втілення, усунення перешкод, боротьбу з невиконанням обов'язків і зловживанням правами й свободами в господарській діяльності, гарантування нормальної реалізації громадянами конституційних прав та свобод людини і громадянина, відновлення їх первинної якості щодо сфери господарювання [8, с. 12].

Більш спеціально поняття адміністративно-правового забезпечення прав і свобод громадян України за кордоном розглядає К. В. Степаненко та визначає дану категорію як регламентовану нормами національного законодавства діяльність органів державної влади, зміст якої становить створення умов для реалізації, охорони та захисту прав громадян України, які перетинають державний кордон або перебувають на території іноземної держави, за допомогою адміністративно-правових засобів [13, с. 14]. Своєю чергою О. М. Дручек характеризує поняття адміністративно-правового забезпечення прав і свобод й інтересів дітей органами внутрішніх справ України як здійснюваний ними в межах визначеної законом компетенції за допомогою спеціального механізму вплив на суспільні відносини з метою захисту, охорони, відновлення прав, свобод та інтересів дитини, а також профілактики та припинення їх порушень [5, с. 127].

Таким чином, у результаті аналізу різних позицій вчених-адміністративістів встановлено, що адміністративно-правове забезпечення в цілому - це сукупність певних дій публічної адміністрації, які спрямовані на 
створення оптимальних умов функціонування механізму держави шляхом прийняття владно-публічних приписів, виконання розпорядчої діяльності, координування протилежних суб'єктів публічної адміністрації, та здійснення інших дій організаційно-правового характеру з метою правового впливу на суспільні відносини та захисту прав, свобод та законних інтересів осіб.

Адміністративно-правове забезпечення у сфері судочинства було об'єктом різних наукових досліджень: зокрема, С. О. Бондар організаційні заходи у сфері забезпечення адміністративних судів об'єднує у такі групи: правові (розробка проектів правових актів з питань діяльності адміністративних судів); організаційно-штатні (розроблення структури адміністративних судів, кадрова робота); охороннопрофілактичні (забезпечення додержання особами, що знаходяться в суді, встановлених правил, виконання ними розпоряджень головуючого в судовому засіданні, підтримання громадського порядку в суді, припинення проявів неповаги до суду, а також охорона приміщень суду, виконання функцій щодо державного захисту суддів, працівників суду, забезпечення безпеки учасників судового процесу); фінансові (розроблення і затвердження єдиних нормативів фінансового забезпечення судів); матеріально-технічні (капітальний ремонт, реконструкція та нове будівництво приміщень судів, а також низка інших витрат, пов'язаних із діяльністю судів); інформаційні (забезпечення судів нормативно-правовими актами, науковою та іншою спеціальною літературою, матеріалами судової практики, даними статистики тощо); організаційно-технічні (забезпечення судів необхідними технічними засобами фіксування судового процесу); науково-методичні (попередній розгляду проектів постанов правових актів, надання висновків щодо проектів законодавчих актів та з інших питань діяльності судів, підготовка яких потребує наукового забезпечення, розробка методичних матеріалів з питань діяльності адміністративних судів) [2, с. 596]. Отже, вчений адміністративно-правове забезпечення адміністративних судів розуміє як певні організаційно-правові заходи, які умовно поділяе на групи.

Адміністративно-правове забезпечення діяльності третейських судів досліджує Н. А. Литвин та визначає його як сукупність правових норм, що регламентують суспільні відносини у сфері третейського розгляду правових конфліктів і спрямовані на правове, організаційне та інформаційне забезпечення діяльності третейських судів в Україні [10, с. 17]. Науковець І. Д. Прошутя під адміністративно-правовим забезпеченням діяльності місцевих загальних судів в Україні розуміє сукупність актів адміністративного законодавства, норми яких визначають ключові засади функціонування місцевих загальних судів в Україні, регулюють особливості адміністративно-правових відносин, в яких зазначені суди беруть участь [12, с. 68].

У контексті нашого дослідження значимою $€$ думка науковця Р. В. Ігоніна, який визначив адміністративно-правове забезпечення функціонування системи судів загальної юрисдикції як регламентовану адміністративноправовими нормами діяльність суб'єктів державно-владних повноважень, яка спрямована на створення необхідних умов для належного функціонування системи судів загальної юрисдикції, та встановлену адміністративноправовими нормами систему гарантій належного функціонування системи судів загальної юрисдикції [6, с. 40]. Суддя А. Л. Борко визначив адміністративно-правове забезпечення функціонування судової системи України як цілеспрямоване здійснення уповноваженими суб'єктами з метою забезпечення нормального функціонування судової системи України, суспільних інтересів і реальності прав громадян за допомогою адміністративно-правових норм та актів індивідуальної дії впорядкування, закріплення, охорони і розвитку організаційно-управлінських та інших відносин у сфері організації та діяльності судової системи України [3, с. 71].

Отже, проаналізувавши позиції науковців, зазначимо, що адміністративно-правове забезпечення функціонування органів судової влади - це визначена та регламентована законодавством діяльність органів державної влади (судової публічної адміністрації та деяких органів виконавчої влади), що забезпечуе оптимальний механізм функціонування судової системи через вчинення різних організаційно-правових та розпорядчих дій публічного характеру, які створюють всі умови правильного функціонування судової системи.

Визначивши основні категорії адміністративно-правового забезпечення, можна дослідити зміст адміністративно-правового забезпечення ефективності функціонування судової влади. Згідно з тлумачним словником української мови, зміст - це те, про що говориться, розповідається де-небудь, те, що описується, зображується; суть, внутрішня особливість чого-небудь; певні властивості, характерні риси, які відрізняють дане явище, предмет від подібних явищ, предметів тощо; розумна основа, мета, призначення чогонебудь [1, с. 624].

Таким чином, базуючись на загальнотеоретичному понятті, зміст адміністративноправового забезпечення ефективності функ- 
ціонування судової влади можна визначити як провідні складники адміністративно-правового забезпечення функціонування органів судової влади, які визначають їхнє місце в суспільстві, а також створюють всі належні умови для правильного функціонування системи правосуддя та ефективності її діяльності.

Щодо елементів змісту адміністративноправового забезпечення ефективності функціонування судової влади, то науковець О. М. Гумін до основних елементів адміністративно-правового забезпечення відносить: об'єкт адміністративно-правового забезпечення; суб'єкт адміністративно-правового забезпечення; норми права (норми адміністративного права); адміністративно-правові відносини та їх зміст; гарантії, заходи, засоби, форми та методи адміністративно-правового забезпечення [4, с. 50].

Ми погоджуємося 3 такою загальною позицією вченого та вважаємо, що до провідних елементів змісту адміністративно-правового забезпечення ефективності функціонування судової влади слід віднести: 1) судову публічну адміністрацію як владний суб'єкт адміністративно-правового забезпечення; 2) об'єкт адміністративно-правового забезпечення ефективності функціонування судової влади; 3) принципи адміністративно-правового забезпечення ефективності функціонування судової влади; 4) адміністративноправові відносини у сфері забезпечення ефективності функціонування судової влади, їх зміст; 5) інші складники змісту адміністративно-правового забезпечення ефективності функціонування судової влади.

\section{Висновки}

Адміністративно-правове забезпечення ефективності функціонування судової влади України - це регламентована законодавством діяльність судової публічної адміністрації, яка здійснюється шляхом прийняття публічних приписів, координування протилежних суб’єктів публічної адміністрації та вчинення інших владно-розпорядчих дій, що спрямовані на реальну ефективність та створення належних умов для функціонування судової влади 3 метою захисту прав, свобод та законних інтересів осіб, суспільства та держави.

До особливостей адміністративно-правового забезпечення ефективності функціонування судової влади України слід віднести таке: 1) це певна діяльність, визначена та передбачена законодавством; 2) провідним суб'єктом є судова публічна адміністрація; 3) спрямоване на ефективність здійснення повноважень судової гілки влади; 4) полягає у вчиненні певних публічно-організаційних дій та прийнятті владних приписів; 5) створене для функціонування судової системи України; 6) належний стан такого забезпечення прямо пов'язаний із захистом прав, свобод та законних інтересів осіб, суспільства та держави.

\section{Список використаних джерел:}

1. Білодід І. К. Словник української мови : в 11-ти т. Київ : Наукова думка, 1970-1980.

2. Бондар С. О. Організаційне забезпечення діяльності адміністративних судів. Актуальні проблеми права: теорія і практика. 2010. № 18. C. 588-596.

3. Борко А. Л. Поняття і основні риси адміністративно-правового забезпечення функціонування судової системи України. Публічне право. 2013. № 2. C. 71-77.

4. Гумін О. М. Адміністративно-правове забезпечення: поняття та структура. Наше право. 2014. № 4. C. 46-50.

5. Дручек О. М. Поняття адміністративноправового забезпечення прав, свобод та інтересів дитини органами внутрішніх справ України. Форум права. 2013. № 2. С. 123-128.

6. Ігонін Р. В. Поняття адміністративно-правового забезпечення функціонування системи судів загальної юрисдикції. Адвокат. 2011. № 1. С. 36-40.

7. Іерусалімова I. О. Механізм адміністративно-правового забезпечення прав і свобод людини та громадянина : автореф. дис... канд. юрид. наук: 12.00.07. Київ, 2006. 20 с.

8. Клименко О. В. Адміністративно-правове забезпечення державної регуляторної політики у сфері господарювання : автореф. дис. ... канд. юрид. наук : 12.00.07. Київ, 2015. 21 с.

9. Лазур Я. В. Поняття, сутність та елементи адміністративно-правового механізму забезпечення прав і свобод громадян у державному управлінні. Форум права. 2009. № 3. С. 392-398.

10. Литвин Н. А. Адміністративно-правове забезпечення діяльності третейських судів в Україні : автореф. дис. ... канд. юрид. наук : 12.00.07. Ірпінь, $2010.20 \mathrm{c}$.

11. Олійник А. Ю. Теорія держави і права : навчальний посібник. Київ : Юрінком Інтер, 2001. $176 \mathrm{c}$.

12. Прошутя I. Д. Адміністративно-правове забезпечення діяльності місцевих загальних судів в Україні. Право і Безпека. 2014. № 4. С. 64-70.

13. Степаненко К. В. Адміністративно-правове забезпечення прав і свобод громадян України за кордоном : автореф. дис... канд. юрид. наук: 12.00.07. Дніпропетровськ, 2009. 19 с.

14. Толкачев К. Б. Органы внутренних дел в механизме обеспечения личных конституционных прав и свобод граждан : монография. Уфа: Уфимская ВШ МВД СССР, 1991. 168 с.

15. Що таке «забезпечення». Словопедія: літературне слововживання. 2015. URL: http://slovopedia.org.ua/32/53399/30821.html (дата звернення: 12.12.2019).

16. Яремко В., Сліпушко О. Новий словник української мови. Київ: Аконіт, 2008. 928 с. 
The article defines the administrative and legal provision effective functioning of the judiciary Ukraine as activities of the judicial of the public administration, which is performed by adopting public provisions, coordination of other entities of public administration, and committing other administrative actions, directed at real efficiency and creating proper conditions for functioning of the judiciary to protect the rights, freedoms and legitimate interests of persons, society and state. It is determined that the content of administrative and legal support for the efficiency of the functioning of the judiciary are the leading components of the administrative and legal support of the functioning of the judiciary, which determine their place in society, as well as create all the necessary conditions for the proper functioning of the justice system and its efficiency. It has been found that the leading elements of the content of administrative and legal support for the efficiency of the functioning of the judiciary are: 1) judicial public administration, as a powerful subject of administrative and legal support; 2) the object of administrative and legal support for the efficiency of the functioning of the judiciary; 3) principles of administrative and legal support for the efficiency of the functioning of the judiciary; 4) administrative and legal relations in the sphere of ensuring the efficiency of the functioning of the judiciary, their content; 5) other components of the content of administrative and legal support for the efficiency of the functioning of the judiciary. It is concluded that the peculiarities of administrative and legal support for the efficiency of the functioning of the judiciary of Ukraine should be attributed to: 1) it is a certain activity, defined and envisaged by the legislation; 2) the leading subject is the judicial public administration; 3) aimed at the efficiency of exercising the powers of the judicial branch; 4) consists in committing certain public-organizational actions and taking power orders; 5) created for the functioning of the judicial system of Ukraine; 6) the proper status of such security is directly related to the protection of the rights, freedoms and legitimate interests of individuals, society and the state.

Key words: administrative and legal provision, content, efficiency, judiciary, public administration. 